\title{
В.С. Білецький
}

\section{ТЕХНОЛОГІЧНІ Й ЕКОЛОГІЧНІ АСПЕКТИ ОСВОЕННЯ ВІТЧИЗНЯНОГО СОЛОНОГО ВУГІЛЛЯ}

Виконано аналіз технологічних та екологічних аспектів освоєння вітчизняного солоно20 вугілля. Надано характеристику сировинної бази солоного вугілля України. Показано технологічні труднощі й екологічні загрози використання солоного вугілля. Описано сучасні технічні рішення з його використання. Виділено найбільш перспективні технології переробки солоного вугілля.

\section{ТЕХНОЛОГИЧЕСКИЕ И ЭКОЛОГИЧЕСКИЕ АСПЕКТЫ ОСВОЕНИЯ ОТЕЧЕСТВЕННЫХ СОЛЕНЫХ УГЛЕЙ}

\begin{abstract}
Выполнен анализ технологических и экологических аспектов освоения отечественного соленого угля. Дана характеристика сырьевой базы соленого угля Украины. Показаны технологические трудности и экологические угрозы использования соленых углей. Onuсаны современные технические решения по их использованию. Выделены наиболее перспективные технологии переработки соленого угля.
\end{abstract}

\section{TECHNOLOGICAL AND ENVIRONMENTAL ASPECTS OF UKRAINIAN SALTY SOUL DEVELOPMENT}

The analysis of technological and environmental aspects of Ukrainian salty coal development is executed. The characteristics of raw material base of salty coal Ukraine are given. Technological difficulties and environmental threats of using salty coal are shown. Modern technical decisions on the usage of salty coals are described. More perspective technologies for salty coal processing are scrutinized.

ПОСТАНОВКА ПРОБЛЕМИ

ТА СТАН IIÏ ВИРІШЕННЯ

«Солоним» називають вугілля 3 підвищеним вмістом оксиду натрію $\left(\mathrm{Na}_{2} \mathrm{O}\right)$ у вугіллі або його золі $[1,2]$. Причому, в різних країнах існують різні критерії віднесення вугілля до розряду «солоних. У США солоним вважають вугілля із вмістом $\mathrm{Na}_{2} \mathrm{O}$ понад $0,5 \%$ на суху масу або понад $4 \%$ в золі $[3,4]$, в ФРН до солоного відносять вугілля з вмістом $\mathrm{Na}_{2} \mathrm{O}$ в золі понад $2 \%$ [4]. Теплотехнічний інститут (ВТИ, Росія) прийняв як порогове значення вмісту $\mathrm{Na}_{2} \mathrm{O}$ у вугіллі 0,4\% [3]. Інститутом геологічних наук НАН України вирішено вважати солоним вугілля, що містить 5,5\% оксиду натрію в золі [2]. В Англії та Австралії прийнято два критерії віднесення вугілля до розряду солоного - за вмістом оксиду натрію (порогові значення: 4,5\% в золі і 1\% у сухому вугіллі) та вмістом хлору на суху масу вугілля - 0,5\% хлору вважається гранично допустимим [5].

Проблема видобування і використання солоного вугілля постала з середини XX ст. У 1950 - 60-х роках на засоленому вугіллі працювало ряд теплоелектростанцій Англії, США та ФРН [2]. Однак серйозні труднощі, 
викликані шлакуванням і корозією поверхонь нагріву котлів послужили причиною заміни ТЕС своєї сировинної бази. В результаті шахти, що добували лужне вугілля були закриті, і перед дослідниками гостро стало питання пошуку нових прийнятних технологій їх використання.

Але попри широкі й багатопланові дослідження, огляд яких виконаний нами в [6 - 8], слід констатувати, що ефективної технології облагороджування вугілля до сьогодні не запропоновано. Можливо, причина цього частково полягає у певній «закритості» проблеми 3 огляду на «діоксинову тематику». Водночас, необхідно підтримувати широку наукову дискусію в цій царині, залучивши до неї також фахове середовище практиків.

Мета цієї статті - аналіз технологічних та екологічних аспектів освоєння вітчизняного солоного вугілля. Для досягнення цієї мети слід виконати такі завдання:

- охарактеризувати сировинну базу солоного вугілля України,

- розкрити технологічні труднощі й екологічні загрози використання солоного вугілля,

- охарактеризувати сучасні технічні рішення з використання солоного вугілля,

- виділити найбільш перспективні технології облагороджування солоного вугілля для його ефективної й екологічно чистої переробки.

Виклад основного матеріалу доцільно побудувати згідно поставлених завдань.

\section{СИРОВИННА БАЗА СОЛОНОГО ВУГІЛЛЯ УКРАЇНИ}

В Україні солоне вугілля виявлене на західній і північній околицях Донецького басейну [6]. Тут розвідані значні (близько 25 млрд т, тобто близько 5\% всіх розвіданих запасів вугілля [3]) запаси найбільш слабкометаморфізованого кам'яного і перехідного до бурого вугілля, які виявилися засоленими. До них віднесені вугільні пласти нижнього карбону на західній околиці, а також середнього карбону на північній i на західній околицях басейну. Вміст $\mathrm{Na}_{2} \mathrm{O}$ в золі вугілля на площах 3 найбільш солоним вугіллям (Новомосковське родовище) в середньому становить $5-10 \%$, місцями досягаючи 15 - 17\%; у перерахунку на сухе паливо воно відповідно дорівнює 0,60,8\% i 1,2 - 1,5\%. Східна межа площі поширення солоного вугілля в Західному Донбасі проходить східніше Новомосковського вугленосного району, а південний у Північному Донбасі, приблизно по Північно-Донецькому насуву. Західна межа в Західному Донбасі та північний - у Північному Донбасі знаходяться за межами розвіданих площ. Отже, солоне вугілля України зосереджене в Новомосковському і Петриківському (Західний Донбас) родовищах, а також на Старобільській вугленосній площі та в Міллеровському вугленосному районі (Північний Донбас, Богданівське родовище). Вугілля віднесене до марки Д. На глибоких горизонтах вугілля переходить в газове. Новомосковське родовище має біля 100 вугільних пластів, 32 з яких робочої потужності (0,6 - 4,45 м). Старобільське і Міллеровське родовища містять відповідно 57 пластів (14 - робочої потужності 0,45 - 3,2 м) і 28 пластів (4 потужності 0,45 - 2,35 м). Глибина залягання промислово перспективних пластів коливається в межах 100 - 1500 м. Бокові породи представлені в основному аргілітами, алевролітами і пісковиками, прошарками вапняків. Вугільні пласти мають переважно просту будову, пологі.

Державним інститутом мінеральних ресурсів України складені прогнозні карти солоності вугільних пластів Донбасу, які розповсюджуються на Новомосковський, Павлоградський, Петриківський, Лозовський, Червоноармійський, ЧистяковоСніжнянський, Старобільський, Лисичанський, Мар'ївський, Селезневський, Луганський, Хрустальський, Краснодонський, Должано-Ровенецький, ШахтинськоНесветаєвський, Сулино-Садкинський, Гуково-Звірівський, Камінсько-Гундорівський, Білокалінвенський і Міллеровський геолого-промислові райони. При цьому ка- 
рти солоності охоплюють вугільні пласти $k_{2}-k_{2 \mu} ; l_{3}, m_{3}, c_{1}, f_{1}, h_{8}$. Отримані дані свідчать про те, що солоність вугілля знаходиться в зворотній залежності від ступеня метаморфізму.

Петрографічні характеристики солоного вугілля Новомосковського родовища, виконані в ІНФОВ НАН України (Мацен- ко Г.П.), представлені в табл. 1. Вугілля нижнього карбону переважно кларенодюренове, містить значну кількість непрозорої основної маси і фюзинітових тканин. Для нього характерний знижений вміст геліфікованої речовини і підвищений - кутинізованих компонентів.

ПЕТРОГРАФІЧНІ ХАРАКТЕРИСТИКИ СОЛОНОГО ВУГІЛЛЯ НОВОМОСКОВСЬКОГО

Таблиця 1

РОДОВИЩА $V_{T}, I, L, M, \%$ [7]

\begin{tabular}{|l|c|c|c|c|c|}
\hline Пласт, свердловина & $V_{t}$ & $I$ & $L$ & $M$ & $R, \%$ \\
\hline$C_{1}, 2-2$ & 71 & 9 & 13 & 7 & 0,48 \\
\hline$C_{4}, 3-3$ & 45 & 28 & 19 & 8 & 0,47 \\
\hline$C_{6}, 3-3$ & 32 & 31 & 23 & 14 & 0,51 \\
\hline$C_{4}, 4 \mathrm{a}$ & 52 & 33 & 15 & 0 & 0,48 \\
\hline$C_{5}, 4 \mathrm{a}$ & 42 & 33 & 16 & 9 & 0,48 \\
\hline$C_{6}, 4 \mathrm{a}$ & 59 & 28 & 10 & 3 & 0,48 \\
\hline$C_{7}, 4 \mathrm{a}$ & 42 & 40 & 18 & 0 & 0,48 \\
\hline$C_{10}, 7 \mathrm{~B} 116$ & 54 & 26 & 15 & 5 & 0,51 \\
\hline$C_{6}, 2-4$ & 53 & 24 & 16 & 7 & 0,45 \\
\hline$C_{7}, 2-4$ & 44 & 45 & 11 & 0 & 0,48 \\
\hline
\end{tabular}

Пластова зольність частіше за все становить $10-15 \%$, у вугільних пачках $-3-7 \%$. Підвищена зольність вугілля спостерігається на півдні родовища.

Солоність українського вугілля в основному зумовлена наявністю в ньому натрію та хлору у співвідношенні, відносно близькому до стехіометричного для галіту.

Середній хімічний склад золових компонентів для вугілля нижнього карбону i середнього карбону (за Е.П. Діком) представлений у табл. 2, а хімічний склад золи деяких пластів Новомосковського родовища - у табл. 3.

Як видно з даних табл. 3, хімічний склад золи солоного вугілля навіть в межах одного пласта нестабільний, що ускладнює технологію їх переробки.

СЕРЕДНІЙ ХІМІЧНИЙ СКЛАД ЗОЛОВИХ КОМПОНЕНТІВ ДЛЯ СОЛОНОГО ВУГІЛЛЯ

Таблиця 2 НОВОМОСКОВСЬКОГО РОДОВИЩА, \% [7]

\begin{tabular}{|c|c|c|}
\hline Золовий компонент & Вугілля нижнього карбону & Вугілля середнього карбону \\
\hline $\mathrm{SiO}_{2}$ & 35,4 & $5,0-48,3$ \\
\hline $\mathrm{TiO}_{2}$ & 1,0 & $0,14-1,7$ \\
\hline $\mathrm{Al}_{2} \mathrm{O}_{3}$ & 19,0 & $3,0-35,4$ \\
\hline $\mathrm{Fe}_{2} \mathrm{O}_{3}$ & 19,6 & $2,4-63,6$ \\
\hline $\mathrm{CaO}$ & 11,5 & $3,3-26,0$ \\
\hline $\mathrm{MgO} O$ & 3,1 & $1,1-8,8$ \\
\hline $\mathrm{K}_{2} \mathrm{O}$ & 2,0 & $0,6-2,8$ \\
\hline $\mathrm{Na}_{2} \mathrm{O}$ & 8,4 & $4,0-14,8$ \\
\hline
\end{tabular}




\begin{tabular}{|c|c|c|c|c|c|c|c|c|}
\hline Пласт, свердловина & $\mathrm{SiO}_{2}$ & $\mathrm{Fe}_{2} \mathrm{O}_{3}$ & $\mathrm{CaO}$ & $\mathrm{MgO}$ & $\mathrm{SO}_{3}$ & $\mathrm{Al}_{2} \mathrm{O}_{3}$ & $\mathrm{~K}_{2} \mathrm{O}$ & $\mathrm{Na}_{2} \mathrm{O}$ \\
\hline$C_{1}, 2-2$ & 13,3 & 13,0 & 20,0 & 4,4 & 22,4 & 13,3 & 1,5 & 12,0 \\
\hline$C_{4}, 3-3$ & 21,1 & 30,1 & 7,9 & 2,8 & 13,5 & 13,7 & 1,3 & 9,3 \\
\hline$C_{6}, 3-3$ & 33,9 & 15,9 & 7,8 & 4,0 & 10,2 & 14,8 & 1,8 & 10,6 \\
\hline$C_{1 \text { ви }}, 4 \mathrm{a}$ & 22,9 & 19,7 & 11,3 & 3,6 & 8,4 & 20,7 & 1,3 & 10,6 \\
\hline$C_{1 \text { ни }}, 4 \mathrm{a}$ & 25,4 & 12,5 & 10,0 & 2,4 & 14,7 & 20,0 & 1,3 & 12,5 \\
\hline$C_{4}, 4 \mathrm{a}$ & 22,2 & 29,1 & 11,3 & 1,9 & 15,3 & 11,8 & 0,7 & 6,6 \\
\hline$C_{5}, 4 \mathrm{a}$ & 44,8 & 7,5 & 16,7 & 2,4 & 11,3 & 11,1 & 1,9 & 4,0 \\
\hline$C_{6}, 4 \mathrm{a}$ & 15,7 & 34,5 & 9,6 & 2,6 & 10,9 & 13,2 & 0,5 & 8,3 \\
\hline$C_{7}, 4 \mathrm{a}$ & 29,7 & 23,1 & 9,4 & 3,4 & 7,2 & 18,8 & 0,6 & 7,1 \\
\hline$C_{4}, 2-4$ & 21,1 & 30,8 & 7,9 & 2,8 & 13,5 & 12,7 & 1,3 & 9,3 \\
\hline$C_{6}, 2-4$ & 7,6 & 46,9 & 9,1 & 2,6 & 18,6 & 6 & 0,6 & 8,0 \\
\hline$C_{7}, 2-4$ & 29,8 & 31,8 & 4,5 & 1,5 & 3,1 & 21,1 & 1,3 & 6,5 \\
\hline
\end{tabular}

Вугілля Новомосковського родовища малосірчисте $(S<2 \%)$ і середньосірчисте ( $S=2-3 \%$ ). Переважає сульфідна сірка [4].

Аналізуючи зв'язок вмісту $\mathrm{Na}_{2} \mathrm{O}$ в солоному вугіллі різних родовищ від хімічного складу золи, слід відзначити його неоднозначність, хоча за рядом хімічних сполук, зокрема $\mathrm{Fe}_{2} \mathrm{O}_{3}, \mathrm{SiO}_{2}, \mathrm{MgO}$ простежується їх чітка взаємозалежність від вмісту $\mathrm{Na}_{2} \mathrm{O}$. Це, очевидно, свідчить про спільність чинників, що викликали озолення цими компонентами вугільної маси. Виявлений високий зворотно-пропорційний зв'язок між загальною зольністю вугілля i вмістом $\mathrm{Na}_{2} \mathrm{O}$ (коефіцієнт кореляції 0,587 [4]) може бути пояснено тим, що неорганічні компоненти вугілля сорбують натрій в значно меншій кількості, ніж органічні [10]. Що стосується зв'язку вугільної речовини 3 петрографічними компонентами, то за даними [10] натрій пов'язаний насамперед $з$ вітринітом.

Вивчення впливу ряду геологічних чинників на вміст $\mathrm{Na}_{2} \mathrm{O}$ в золі вугілля не виявив помітної залежності вмісту $\mathrm{Na}_{2} \mathrm{O}$ від потужності вугільного пласта, глибини його залягання, відстані до розривних порушень, відстані до зони виклинювання пласта.

Дослідженнями встановлено, що зола солоного вугілля і мінеральний склад вмісних порід істотно відрізняються за хімічним складом. У порівнянні з вмісними по- родами, зола вугілля має знижений вміст оксидів кремнію, калію, алюмінію і підвищений - оксидів заліза, кальцію, сірки, магнію і натрію. Крім глинистих мінералів солоне вугілля містить пірит, карбонати кальцію, магнію і заліза. Вміст $\mathrm{Na}_{2} \mathrm{O}$ в золі вугілля в $9-11$ раз вищий, ніж у мінеральній складовій порід. Що стосується вмісту хлору, то він у вугіллі в $10-14$ раз вищий, ніж у вмісних породах.

\section{ТЕХНОЛОГІЧНІ ТРУДНОЩІ Й ЕКОЛОГІЧНІ ЗАГРОЗИ ВИКОРИСТАННЯ СОЛОНОГО ВУГІЛЛЯ}

Існують три головні проблеми в технологічному й екологічному плані використання солоного вугілля. По-перше, його спалювання спричиняє інтенсивне шлакування робочих поверхонь котлоагрегатів, суттєве зниження їх ККД. По-друге, при спалюванні такого вугілля спостерігається підвищена корозія металу. По-третє, в атмосферу виділяються токсичні хлористі сполуки, й існує підвищена імовірність утворення високотоксичних діоксинів. Зупинимося на цих моментах докладніше.

Золові відкладення на робочих поверхнях котлоагрегатів дають всі неорганічні компоненти вугілля, зокрема найбільше легкоплавкі (галіт - температура плавлення біля $800^{\circ} \mathrm{C}$ ). Осідаючи на робочих поверхнях, а також на частинках леткої золи галіт істотно підвищує їх клейкість, ство- 
рюючи тим самим умови для формування шлакового шару. При реакції з діоксидом сірки галіт переходить у більш міцний тенардит $\mathrm{Na}_{2}\left[\mathrm{SO}_{4}\right]$. Під дією температури шлакові відклади спікаються, що підвищує ïх міцність, і практично виключає можливість їх видалення звичайними пристроями для очищення. У результаті різко погіршується теплообмін і збільшується температура газів на виході з топки, що знижує ККД агрегату i, в кінцевому результаті, внаслідок інтенсивного шлакування повністю виводить його з ладу [10]. Температура початку шлакування солоного вугілля Новомосковського родовища Західного Донбасу становить $750-850^{\circ} \mathrm{C}$ (при зольності 7,6 - 12\%), тоді як для несолоного вугілля Донбасу вона суттєво вища $1000-1020^{\circ} \mathrm{C}$.

Хлор при спалюванні солоного вугілля виступає як активний прискорювач процесу корозії. Цей ефект спостерігається при вмісті хлору у вугіллі понад 0,5\%. При спалюванні солоного вугілля в атмосферу 3 водяною парою виділяється $\mathrm{HCl}$, а в середовищі вуглекислого газу - молекулярний хлор $\mathrm{Cl}_{2}$. У процесі термоактивації солоного вугілля утворюється також чадний газ $\mathrm{CO}$, хлористий водень $\mathrm{HCl}$, водень $\mathrm{H}_{2}$, метан $\mathrm{CH}_{4}[2,3]$. Крім того, при термопереробці солоного вугілля існує імовірність утворення діоксинів, токсична дія яких значною мірою перевершує дію відомих найсильніших отрут: ціанідів, стрихніну, кураре, зоману, зарину, табуну, VX-газів i iн. [11]. Речовини діоксинового ряду володіють мутагенними властивостями, зменшують імунні можливості організму, нагромаджуючись в організмі, де період напіврозпаду діоксинів складає 6-7 років, викликають різноманітні хвороби і навіть обумовлюють викривлення спіралі молекули ДНК, що спрощує вплив на неї інших речовин. Українські вчені Т. Шендрик, В. Симонова, Л. Потоцька й ін. вважають також вірогідним утворення при термообробці солоного вугілля фосгену $-\mathrm{COCl}_{2}$ [12]. Загалом екологічний аспект термопереробки (зокрема, спалювання) солоного вугілля є вельми важливим компонентом проблеми їх використання, але на сьогодні ще вивчений слабко.

\section{СУЧАСНІ ТЕХНІЧНІ РІШЕННЯ 3 ВИКОРИСТАННЯ СОЛОНОГО ВУГІЛЛЯ}

Пошук ефективних і екологічно прийнятних методів переробки солоного вугілля ведеться в двох принципово різних напрямах: перший передбачає розробку нових способів прямого використання солоного вугілля без видалення натрій- і хлорвмісних домішок; другий передбачає попереднє знесолення (збагачення вугілля по солі) 3 подальшим використанням кондиційного продукту в топках (або інших процеcax).

Перший напрям включає як традиційний спосіб використання малометаморфізованого солоного енергетичного вугілля ïx спалення на TEC, котельних, так і пошук нових шляхів використання незбагаченого солоного вугілля - піроліз, газифікація, зрідження, напівкоксування, комплексна переробка з виділенням гуматів.

У Німеччині та Великобританії випробувано технологію спалювання попередньо збідненого глиною солоного вугілля [13]. Це найбільш просте рішення, однак значне зменшення теплотворної здатності вугілля суттєво знижує техніко-економічні показники процесу.

Технічні рішення [14-15] передбачають спеціальні добавки до солоного вугілля, які нейтралізують негативний вплив лужних солей при їх спалюванні. Добавками слугують силікати лужних металів, кремнієві кислоти, кварц, оксид магнію, веруліт. У Великобританії та Німеччині успішно випробувані як спеціальні добавки до солоного вугілля сполуки $\mathrm{Mg}$ і $\mathrm{Ca}$, які нейтралізують несилікатний натрій.

У Німеччині здійснена спроба створення спеціальних топок хлоридного горіння. Це забезпечує спалення палива при зниженій температурі та максимально швидке зниження температури димових газів, що в 
комплексі повинно різко знизити або навіть усунути шлакування робочих поверхонь при використанні солоного вугілля. Однак випробування таких топок не дали очікуваних задовільних результатів, і подальші роботи в цьому напрямі були припинені [2].

Спалення солоного вугілля в котлах 3 циклонними топками і рідким шлаковидаленням паропродуктивністю 100 і 125 т/год на одній з фірм VEB (Східна Німеччина) показало, що специфічні відкладення на робочих поверхнях котлів спостерігаються при вмісті $\mathrm{Na}_{2} \mathrm{O}$ в золі $2 \%$ і більше [16].

У США солоне вугілля спалюють в топках, обладнаних додатковим пристроєм очищення екранів. Однак, ці заходи виявилися неприйнятними для очищення поверхонь пароперегрівачів через виникнення термічних напружень в трубах.

У Німеччині виконано дослідницькі роботи 3 напівкоксування солоного вугілля. Встановлено, що при переробці цим методом вугілля родовища Мерсебург-Схід близько 50\% оксиду натрію і $60-80 \%$ хлору переходить у напівкокс. Вихід рідких продуктів залежно від режимів коксування коливається в межах $5-50 \%$.

У США, Україні та ФРН виконано досліди щодо зрідження солоного вугілля [1]. Лабораторні дослідження 3 гідрогенізації солоного вугілля Новомосковського родовища (Україна) показали можливість перетворення органічної маси вугілля на рівні $72-81 \%$. При цьому основна маса натрію (95 - 97) і хлору $(94-98)$ концентрується в твердому залишку. При гідрогенізації солоного вугілля Німеччини кількість цільового рідкого і газоподібного продукту становила 53\%. Ніяких істотних технологічних ускладнень на лабораторному етапі досліджень не виявлено. Однак при зрідженні рядового солоного вугілля 3 родовищ штату Кентукі (США) на пілотній установці спостерігалася активна корозія робочих поверхонь дистиляційної колони. Це, очевидно, було викликане присутністю в продуктах кислоти $\mathrm{HCl}$. Загалом же, отримані результати оцінені дослідниками як позитивні, а переробка солоного вугілля гідрогенізацією визнана перспективним напрямом.

Низку способів переробки солоного вугілля без операції спеціального знесолювання запропоновано також українськими вченими Дніпропетровського хімікотехнологічного інституту, Інституту фізико-органічної хімії і вуглехімії НАН України, Інституту проблем моделювання в енергетиці НАН України. На них ми детально зупинимося нижче.

Інший напрям, що передбачає попереднє збагачення вугілля по солі (знесолювання), опрацьований у низці дослідницьких центрів $[1,2,6,7]$. Причому, найбільша частина запропонованих рішень основана на різних варіантах водної промивки солоного вугілля. Це, зокрема, технології Державного інституту мінеральних ресурсів України, НВО «Хаймек», Донецького національного технічного університету.

У США запропоновано природне відмивання від солі (вміст хлору знижується в 3 - 4 рази) при його складуванні на відкритому повітрі, але результати знесолювання сильно залежать від кількості опадів і важко прогнозуються. Крім того, вугілля при тривалому зберіганні окислюється, відбувається активне засолення грунтів у районі складування солоного вугілля.

Таким чином, проблема переробки солоного вугілля активно вивчається вченими ряду країн і певні успіхи досягнуті як в області прямого їх використання, так і в збагаченні по солі.

Найбільш перспективні технології облагороджування і використання солоного вугілля $з$ точки зору його ефективної й екологічно чистої переробки, очевидно, повинні відрізнятися простотою, технологічністю, екочистотою, економічністю. До таких сьогодні слід віднести вузьке коло технічних рішень, які передбачають спеціальні добавки, що нейтралізують негативний вплив лужних солей при їх спалюванні.

Крім того, перспективними для подальших досліджень слід вважати технології спалювання вугілля у вигляді висококон- 
центрованих суспензій (водо-вугільних, водо-вугле-масляних тощо), а також технології зрідження вугілля, його термічної переробки (піроліз), підземної газифікації солоного вугілля.

\section{ВИСНОВКИ}

1. Задача освоєння «солоного вугілля» об'єктивно постає в кожній країні зі значимими їх запасами, зокрема в Україні, яка має близько 25 млрд т такого вугілля (Західний і Північний Донбас), тобто близько $5 \%$ всіх розвіданих запасів вугілля.

2. Існують принципові технологічні труднощі й екологічні загрози використання солоного вугілля, які полягають в інтенсивному шлакуванні робочих поверхонь котлоагрегатів (суттєве зниження їх ККД), підвищеній корозії металу і виділенні в атмосферу токсичних хлористих сполук та, за деякими даними, високотоксичних діоксинів.

3. На сьогодні, як за кордоном, так і в Україні, немає технологічно простого та водночас економічно ефективного вирішення проблеми освоєння «солоного вугілля». Найбільше наблизилася до цього газифікація в циркулюючому киплячому або фонтануючому шарах, що поєднує перевагу потокового процесу і процесу в киплячому шарі, 3 подальшим спаленням очищених продуктів газифікації, а також гідрогенізація. Радикальним вирішенням проблеми переробки солоного вугілля, очевидно, можуть бути технології підземної газифікації та зрідження солоного вугілля 3 подальшим очищенням зріджених продуктів від шкідливих домішок.

4. Перспективний напрям дослідження проблеми - приготування і спалювання на основі солоного вугілля висококонцентрованого водовугільного палива.

\section{СПИСОК ЛІТЕРАТУРИ}

1. Шендрик Т.Г. Соленые угли / Т.Г. Шендрик, В.І. Саранчук. - Донецк: Східний видавничий дім, 2003. - 296 с.

2. Афанасенко Л.Я. Исследование характеристик и свойств засоленных углей Донбасса и их изменений при термической обработке: автореф. дисс. на соискание науч. степени канд. техн. наук / Л.Я. Афанасенко. - К., 1990. -20 c.

3. Исследование электрофизических и физикохимических свойств "соленых» углей: отчет о НИР (промежуточ.) / Ин-т физикоорганической химии и углехимии АН Украины; рук. В.И.Саранчук; ГР 0185.0013540. - Донецк, 1985. -82 с.

4. Методические разработки по изучению соленых углей Западного Донбасса / [Пожидаев С.А., Грицай Р.А., Иванова А.В. и др.]. - К.: Наукова думка, 1981. - 56 с.

5. Хаушильд М. Котлы для сжигания бурых углей с большим содержанием щелочей в золе / М. Хаушильд // Паровые котлы зарубежных электростанций. - М. Л.: Госэнергоиздат, 1959. - Вып. 1. - С. 23 - 42.
6. Перспективы освоения соленых углей Украины / [Белецкий В.С., Пожидаев С.Д., Кхелуфи А. и др.]. - Донецк: Східний видавничий дім, 1998. - 96 с.

7. Білецький В.С. Проблема переробки солоного вугілля / В.С. Білецький // Праці наук. т-ва ім. Шевченка. Т. Х: Хемія та біохемія. - Л., 2003. - С. 205 - 227.

8. Білецький В.С. Проблема солоного вугілля: світовий та вітчизняний досвід / В.С. Білецький // Збагачення корисних копалин. - 2009. - Вun. 36 (77)/37(78). C. $230-252$.

9. Зайковский А.В. Изменение структуры и свойств продуктов щелочного гидролиза соленых углей Западно20 Донбасса: автореф. дисс. на соискание науч. степени канд. хим. наук / А.В. Зайковский. - Донецк, 1993. - 19 с.

10. Иванова А.В. Соленые угли Западного Донбасса / А.В. Иванова, Т.А. Кривега. - К.: Наукова думка, 1985. $109 \mathrm{C}$.

11. Строение и свойства диоксинов / [Хазипов В.А., Галушко Л.Я., Пащенко Л.В. и др.] // Химия твердого топлива, 1995. - № 4. - С. $67-72$.

12. The Ways of Diffirent Types of Sorbents Obtaininr from Chlorine-Containing Coals: Ecological Aspects /[Shendrik T., Siminova V., Pototska L. and etc.] // Int. 1996 
European Carbon Conference. - Newcostle-upon-Fyne, 7 - 2 July, 1996.

13. Clorene in Coal: a Review of its Origin and Mode of Occurence / N.J. Hodges, W.R. Ladner, T.G. Martin // J. Inst. Energy. - 1983. - № 128. - P. 58 - 169.

14. The Influence of Vineral Interactions upon the Behaviour of Sodium during Combustion / A.J. Botting, N.J. Hoges, D.G. Richards, F.O. Wood // Int. Conf. Coal Sci.: Abstr. - Tokio, 1989. - № 1. - P. $63-66$.

15. Заявка 56-166299, МКИ C101L9110. Cпособ переработки каменного угля, содержащего соединения щелочных и щелочноземельных металлов / Н. Кэйо, О. Дзю- нье, Й. Сидзуо, К.К. Кобэ сэйкосе (Япония). - № 55. 58410; заявл. 30.04.80; опубл. 21.12.81.

16. Lehman H. Zur Kenntnis des eozanen Salzkohlen /H. Lehman // Bergbantechnik, 1967. - № 7. - P. 350 355.

\section{ПР0 АВTOPIB}

Білецький Володимир Стефанович - д.т.н., професор кафедри збагачення корисних копалин Донецького національного технічного університету. 